\title{
DIE NUWE ONDERWYSBELEID IN TRANSVAAL.
}

\section{OMSKRYWING VAN OORSIG.}

Onder die nuwe onderwysbeleid word verstaan nie die voortclurende veranderings wat deel van 'n dinamiese stelsel uitmaak, nie die Taalordonnansie nie, maar wel die beleid wat teen die end van 1950 deur die provinsiale owerheid aangekondig, en vanjaar in werking gestel is.

Die onderwerp word verder beperk deur die aandag op slegs enkele uitstaande aspekte van die nuwe beleid toe te spits.

\section{DIE AANLEIDING TOT 'N NUWE BELEID.}

Om die nuwe beleid beter te kan begryp, sal dit nodig wees om aan te toon wat daartoe aanleiding gegee het.

In hierdie kort bestek sal dit nie moontlik wees om die ondersoek na oorsese lande of ver in die verlede terug te voer nie, maar om te volstaan by die Verslag van die Provinsiale Onderwyskommissie van 1937 (die Nicolkommissie) en die Verslag van die Kommissie insake Tegniese 
en Beroepsonderwys van 1948 (die De Villiers-kommissie). Na hierdie verslae sal onderskeidelik as "N" en "V" verwys word. Die syfers dui telkens die betrokke paragrawe in die onderskeie verslae aan.

\section{AARD VAN DIE WYSIGINGS.}

Die nuwe beleid betref eerder die organisasie as die doelstellings, die inhoud of die metodiek. Soos hieronder sal blyk, is die wysigings nie uit die lug gegryp nie maar kan hulle na die aanbevelings van minstens een van die begemelde kommissies herlei word.

\section{Die Juniorhoërskool.}

Die aanskoulikste verandering is die afskaffing van die juniorhoërskool wat sy ontstaan aan die Nicol-kommissie te danke gehad het.

Hierdie kommissie het aanbeveel dat daar twee alternatiewe kursusse vir die middelbare onderwys moet bestaan, 'n vyfjarige akademiese kursus aan die tradisionele hoërskool, en 'n driejarige praktiese kursus aan 'n gevorderde skool, later as die juniorhoërskool bekend (N.272). Waar die getal leerlinge die stigting van afsonderlike skole vir die twee kursusse nie regverdig nie, moet parallele kursusse in dieselfde skool aangebied word (N.273).

Aan die end van die laerskoolkursus moet beroepsvoorligting verskaf word, en die juniorhoërskool moet minstens een jaar lank vir gedifferensieerde onderwys voorsiening makk (U.279). Die leerling moet 'n aansienlike aantal vakke uit 'n groot verskeidenheid kies om hom in staat te stel om sy aanleg te bepaal. Baie aandag moet aan liggaamlike en kulturele onderwys gegee word om sy liggaam sterk en gesond te maak en sy gees te beskaaf. Hoofsaaklik gedurende die derde jaar van die kursus moet 'n mate van voorberoepsonderwys aangebied word om die leerling vir beroepsonderwys voor te berei.

Die opset van die juniorhoërskool was prysenswaardig, en dit sou beter geslaag het as die skool hom suiwer by hierdie doelstellings bepaal het.

Maar die saad van ontbinding is in die opset gesaai toe die kommissie, uit vrees dat sommige leerlinge by die verlating van die laerskool die verkeerde kursus sou kies, aanbeveel het dat die kursus van die juniorhoërskool in so 'n groot mate met die van die hoërskool moet ooreenstem dat 'n leerling maklik van eersgenoemde na laasgenoemde oorgeplaas kan word: 'n brug moet tussen die twee bewaar word. Juis dit het die doel van die juniorhoërskool verydel: hy kon nóg akademies nóg prakties wees. Gevolglik het hy eerder akademies as prakties van aard geword, en is sy werk tot sy nadeel met die van die hoërskool vergelyk.

By die toepassing van die beleid is ' $n$ verdere fout begaan wat regstreeks tot die afskaffing van die juniorhoërskool gelei het. Weens gebrek 
aan personeel en hulpmiddele het die beoogde beroepsvoorligting in die laerskool hoofsaaklik op verstandsmeting uitgeloop. Daar is van die standpunt uitgegaan dat leerlinge met hoë intelligensie vir akademiese onderwys aangelê is en dat leerlinge met laer intelligensie prakties aangelê is. Eersgenoemde groep is vir die hoërskool aangewys, en laasgenoemde vir die juniorhoërskool. Behoorlike beroepsvoorligting sou sonder twyfel in baie gevalle op ' $n$ ander verdeling uitgeloop het. Geen wonder dat die juniorhoërskool as die „dom-skool” gekenmerk gestaan, en sy leerlinge as dom gebrandmerk is nie. Werkgewers het voorkeur aan die produkte van die hoërskool gegee. Dit het die juniorhoërskool by leerlinge, ouers sowel as die publiek in 'n slegte reuk gestel.

Met die verloop van tyd het onderwysers sowel as ouers van kinders in die juniorhoërskool daarop begin aandring dat die voorberoepsonderwys in sekere rigtings, tik- en snelskrif, volbloed beroepsonderwys moet verskaf. By die verlating van die skool moet leerlinge in staat wees om kantoorwerk te kan onderneem. Die skool was ook besig om in daardie rigting te beweeg. Dit sou hom egter mettertyd in botsing met die beroepskool bring.

Die De Villiers-kommissie het die foute en gebreke van die juniorhoërskool raakgesien en planne beraam om hom op 'n beter voet te stel.

Hy het anbeveel (V.323) dat alle leerlinge, nie net die minderbegaafdes of diegene met praktiese aanleg nie, na die juniorhoërskole oorgeplaas moet word soos dit in baie oorsese lande geskied (V.143). Hier moet die onderwys algemeen van aard wees (V.125), dit moet breed wees en vir individuele verskille voorsiening maak. Alle leerlinge moet sekere. „basiese studies" (die twee tale, rekenkunde en elementêre wiskunde) volg, en verder moet daar 'n breë vakkeuse bestaan. Die doel was die ontwikkeling van die hele persoonlikheid. Sistematiese beroepsvoorligting moet voortdurend toegepas word om die aanleg en belangstellings van die leerling vas te stel (V.275). Die skool moet dien as „'n klaringshuis" na die akademiese hoërskool, die handels- of die tegniese hoërskool (V.323). Die juniorhoërskool sal egter ,nie, soos in die bestaande inrigtings wat die naam in Transvaal dra, georganiseerde beroepsopleiding in enige vorm verskaf nie" (V.478).

In die stede moet hierdie skole volop bestaan, en feitlik elke dorpie moet oor een beskik. In die kleiner dorpe moet hulle selfs bestaande hoërskole vervang (V.484).

By monde van hulle organisasie, die Transvaalse Onderwysersvereniging, het die Afrikaanssprekende onderwysers die praktiese kursus van die juniorhoërskool onderskryf, met die aanbeveling dat dit 'n mate van beroepsonderwys moet insluit, maar het hulle die bestaan van die junior- 
hoërskool as 'n afsonderlike skool onvoorwaardelik afgekeur. Hulle het gekom met die slagspreuk: alle onderwys onder een dak. Waar enigsins moontlik, moet alle juniorhoërskole tot volwaardige hoërskole ontwikkel, en alle hoërskole moet akademiese sowel as praktiese kursusse tot standerd X aanbied. Die praktiese kursusse moet selfs tegniese onderwys insluit. Die motief was dat 'n leerling nie gebrandmerk moet staan vanweë die skool wat hy besoek het nie, dat die ontwikkeling van klasseverskille (geleerdes, amptenare en arbeiders) bestry moet word, en dat daar eenheid van beheer oor alle onderwys in die provinsie moet bestaan.

Nadat die owerhede al hierdie getuienis in aanmerking geneem het, het hulle blykbaar saam met die onderwysers tot die oortuiging gekom dat die juniorhoërskool misluk het. Hierdie opvoedingsinrigting is afgeskaf en niemand het sy heengaan beween nie. Hoe anders kon dit gewees het as die juniorhoërskool toegelaat was om onafhanklik van die akademiese hoërskool 'n eie karakter te ontwikkel, om die oorspronklike doel wat die Nicol-kommissie beoog het, getrou na te streef. Dan sou hy nie tot sy nadeel met die hoërskool vergelyk geword het nie, en sou hy 'n groot leemte gevul het. Met die beste bedoelings van die Nicol-kommissie en die beroepsvoorligters het die skool ten gronde gegaan.

Die aanbeveling van die De Villiers-kommissie, naamlik dat alle leerlinge by die verlating van die laerskool drie jaar in die juniorhoërskool moet vertoef, sou die skool gewis in 'n beter lig gestel het; dit sou nie meer as die "dom-skool" bekend gestaan het nie en alle vooroordeel sou opgehef gewees het. Daar kan ook veel ten gunste van die voorgestelde leerplan gesê word. Die sterkste aanbeveling vir die skema is dat leerlinge drie jaar lank algemene onderwys moet ontvang voordat hulle begin spesialiseer, voordat hulle selfs 'n ambag kan gaan leer.

In ooreenstemming met die aanbeveling van die onderwysers het dic juniorhoërskole volwaardige hoërskole geword. Waar die getal leerlinge dit nie geregverdig het nie, is hulle weer aan laerskole gekoppel om die sogenaamde Groep II-skole uit te maak.

\section{DIE HOERSKOOL.}

Soos hierbo gesien, het die Nicol-kommissie die tradisionele hoërskool voorgestaan.

Die De Villiers-kommissie het aanbeveel dat die hoërskool deur die seniorhoërskool vervang moet word en sy leerlinge uit dic juniorhoërskool moet trek nadat hulle drie jaar daar vertoef het.

Die seniorhoërskool moet 'n tweejarige kursus aanbied vir diegene wat algemene onderwys verlang en die skool na standerd $X$ verlaat, en 'n ,,derdejaar of voor-universiteitskursus as voorbereiding vir student- 
skap" (V.282) vir diegene wat hulle onderwys aan 'n universiteit wil voortsit.

Die ander leerlinge wat die juniorhoërskool verlaat, moet as volg ingedeel word: (a) sommige sal gaan werk en deeltydse onderrig ontvang; (b) die res sal na hoër handelskole, landbouhoërskole of tegniese hoërskole gaan.

Omdat die seniorhoërskool 'n groot vakkeuse moet aanbied om vir individuele verskille voorsiening te maak, moet hy taamlik groot wees. Daarom moet die kleiner plattelandse hoërskole gesentraliseer word (V.484).

Die voorgestelde seniorhoërskool het by die owerhede nie byval gevind nie vermoedelik (a) omdat die owerhede van oordeel was dat twee tot drie jaar te kort sou wees onn 'n behoorlike spangees aan die hoërskool op te bou en die gewenste kultuurleiding te gee, (b) omdat die byvoeging van 'n voor-universiteitsjaar die skoollewe van die jeugdige onnodig lank uitrek, (c) omdat dit die lewe van sommige plattelandse hoërskole bedreig en (d) omdat baie leerlinge die skool sou verlaat eerder as om na 'n ander skool oorgeplaas te word.

Die nuwe beleid bepaal dus dat die tradisionele hoërskool bly voortbestaan en dat die meeste juniorhoërskole volwaardige hoërskole word. Aanvanklik sou sommige stedelike hoërskole net die akademiese kursus, en ander stedelike hoërskole net die praktiese kursus aanbied terwyl die orige hoërskole vir dic akademiese sowel as dic praktiese kursus voorsiening sou mak. Die praktiese kursus is in werklikheid 'n voortsitting van die werk van die juniorhoërskool met die verskil dat dit nie met standerd VIII afsluit nie, maar wel met standerd X. Die aantal leerlinge het egter sodanig aan al die stedelike hoërskole toegeneem, dat daar aan feitlik almal verlof toegestaan is on albei kursusse aan te bied. Die twee skole onder een dak het dus tot voldoening van die onderwysers 'n werklikheid geword.

'n Byvoeging tot die hoërskool is die stigting van 'n aanpassingsklas vir leerlinge wat standerd $\mathrm{V}$ in die laerskool nie voltooi het nie, maar wat onl een of ander rede vertraag geraak het en op ouderdom na die hoërskool oorgeplaas is. Soos die naam aandui, sal die aanpassingsklas 'n besondere poging aanwend om hierdie leerlinge te help om die agterstand in te haal sodat hulle weer by die normale klasse kan aansluit. Diegene wat nie by die normale klasse aangepas kan word nie, sal minstens 'n mate van kulturele, maatskaplike en liggaamlike ontwikkeling kan beleef en 'n sertifikaat verwerf wat hulle in staat sal stel om beroepsonderwys te ontvang.

Later verwys ons weer na hierdfe aspek van die nuwe beleid. 
'n Nuwe instelling is die groot skool in die laer sowel as die middelbare onderwys. Skole met 750 pleks van die gebruiklike 450 leerlinge word beoog. Sommige hoërskole het egter vanjaar reeds tot kort by 'n duisend gegroei.

Ofskoon groot skole in die verlede nie onbekend was nie, is hulle in die lig van 'n noodmaatreëls gesien. Hulle het tydelik bestaan net totdat ander skole afgestig kan word. Nou maak hulle 'n deel van die vaste beleid uit.

Die doel van die groot skool is blykbaar tweërlei: (1) om in die dringende behoefte van skoolruimte te voorsien, en (2) om leerlinge 'n groter vakkeuse te gee. Aan albei heirdie eise sal die groot skool voldoen. Dis naamlik goedkoper om klaskamers aan te bou as om 'n nuwe skool te stig, en daarby word 'n paar pennies, vergelykenderwys gesproke, op die salarisse van skoolhoofde bespaar. In so 'n skool kan daar ook 'n baie ruimer vakkeuse as in die skool van middelmatige grootte gestel word.

Die eerste reaksie van die onderwysers was om die groot skool af te keur. As grond vir hulle kritiek word aangevoer dat die hoof elke leerling moet ken en oor die tyd moet beskik om samesprekings met elkeen te hou. Die praktyk het bewys dat 'n hoof beswaarlik elk van 450 leerlinge kan ken en dat leerlinge vir hom slegs nommers sal word as die getal baie hoër as 450 styg. Die instelling is egter nog nie behoorlik op die proef gestel nie. Moontlik sal hoofde kan leer om hulle met welslae by dic groter skool aan te pas.

Maar sonder twyfel kom die administrasie van die groot skool op iets anders as ' $n$ uitgebreide administrasie van die kleiner skool neer. Omdat ons nie ervaring daarvan het nie, sal ons met ons redenering aanvanklik ernstige foute begaan. Die terrein wat byvoorbeeld vir 'n skool van 450 leerlinge voldoende was, kan 750 leerlinge nie behoorlik dra nie, Die sknolsaal, die sportvelde, die swembad en ander geriewe sal almal ontoereikend wees. Omdat dic meeste skole in geslote gebiede geleë is, kan daar nie grond bygelas word nie. Vir opvoedkundige doeleindes kan oorbevolking slegs 'n nadelige invloed hê.

Die hoof van die groot skool sal noodwendig 'n ander funksie as die hoof van die kleiner skool beklee. In toenemende mate sal hy ' $n$ bestuurder in teenstelling met ' $n$ opvoeder word.

Hierdie aangeleenthede moet sonder uitstel wetenskaplik bestudeer word sodat die groot skool tot die grootste voordeel van die leerlinge ingerig kan word. Die luk-mis metods moet nie gedoog word nie.

In sommige oorsese lande bestaan die groot skool lank reeds, en wel groter skole as wat by ons beoog word. Maar dit beteken nog nie dat 
sodanige skole by ons, wat ander doelstellings in die onderwys beoog, sal beantwoord nie. Dit beteken ook nie dat ons met' $n$ groot aantal leerlinge per onderwyser sal kan uitvoer wat in die buiteland met ruimer personeelvoorsieningskale uitgevoer word nie. Ondersoek en grondige navorsing moet vir ons 'n eie weg aanwys.

\section{BEVORDERING VOLGENS OUDERDOM.}

Die ingrypendste verandering onder die nuwe onderwysbeleid is die bevordering van leerlinge volgens ouderdom.

In Transvaal het die stelsel van bevordering volgens prestasie sedert die vroegste tye bestaan. 'n Kind moes eers die werk van een standerd onder die knie kry voordat hy toegelaat is om die werk van die volgende standerd aan te pak. Dit het meegebring dat sommige leerlinge meer as een maal per jaar bevorder is, en dat andere etlike jare lank in dieselfde standerd gehou is.

Mettertyd is daar egter bepaal dat 'n leerling darem nie ' $n$ onbepaalde aantal jare in dieselfde klas van die laerskool gehou kon word nie. Maar geen besondere voorsiening is vir die vertraagde leerling in die hoër klas gemaak nie. Die aanpassingsklas in die hoërskool en in groot laerskole is 'n nuwigheid.

Die Nicol-kommissie (N.265) ,beveel aan dat alle leerlinge wat hulle veertiende jaar in die laerskool bereik, na die middelbare skool aan die begin van die volgende jaar oorgeplaas word, en namate die gemiddelde ouderdom vir standerd $V$ afneem, die oorplasingsouderdom tot $13 \frac{1}{2}$ jaar en eindelik tot 13 jaar verminder word."

Die De Villiers-kommissie bewys uit statisticke (V.267) dat ongeveer $40 \%$ leerlinge in die lacrskool vertraag is. Om hierdie euwel te bestry beveel hy aan dat leerlinge volgens hulle ouderdom bevorder word en dat hulle op die ouderdom van twaalf plus na die middelbare skool oorgeplaas word sodat alle adolessente die soort onderwys kan ontvang wat hulle nodig het (V.269).

In sy getuienis voor die Nicol-kommissie in 1938 het die Transvaalse Onderwysersvereniging amptelik voorgestel dat lecrlinge volgens hulle ouderdom bevorder moet word, maar dit het later geblyk dat hy daarin waarskynlik nie die sienswyse van die deursnee-onderwyser vertolk het nie.

Die bepaling van die nuwe beleid dat leerlinge volgens hulle ouderdom bevorder moet word, is mét heftige teenkanting deur baie onderwysers, moontlik die meerderheid, begroet. Watter aansporing sal daar vir die leerling bestaan om hom te beywer as hy by voorbaat weet dat hy tog die end van die jaar bevorder sal word? Wat sal van die wêreld word as toekomstige beroepsmanne besoldiging net vir hulle aanwesig- 
heid by die werk verwag en as prestasies nie meer geverg word nie? Hierdie en soortgelyke vrae word gestel.

Die mens is konservatief van aard: hy verset hom gewoonlik teen nuwighede. Die onderwyser is ook mens en derhalwe ook konservatief. Vermoedelik het dieselfde verset hom by "die invoer van hierdie maatreël ook in ander lande geopenbaar. Namate die stelsel bekend word, sal hy waarskynlik ook gewild word. Maar dis gewis en seker dat 'n onderwyser met die gebruiklike klas van veertig oor verskillende stadiums van vordering versprei, nie bevredigende werk sal kan lewer nie. Groot klasse stel 'n homogene groep as voorwaarde. Vir 'n heterogene groep is individuele onderwys ' $n$ vereiste. Selfs in die laerskool behoort sodanige klas tot uiters 25 leerlinge beperk te word. Terwyl ons reeds met ' $n$ tekort aan onderwysers te kampe het, kan hierdie stap 'n voorbarige onderneming blyk te wees.

Ook die bevordering van leerlinge benede die peil van standerd $\mathrm{V}$ na die aanpassingsklas in die hoërskool word sterk afgekeur. Sodra die doel van hierdie maatreël egter beter begryp word, sal dit waarskynlik in 'n gunstiger lig gesien word. Dit ly geen twyfel nie dat baie kinders tans die skool sonder standerd $\mathrm{V}$ verlaat en dat hulle nooit in 'n middelbare skool tereg kom nie. Die gevolg is dat hulle selfs nie tot die eenvoudigste geskoolde arbeid toegelaat kan word nie. In die aanpassingskias kan hulle waarskynlik „rypgedruk" word om 'n standerd Vl-sertifikaat te ontvang wat hulle van die geledere van die ongeskoolde arbeidsmark kan vrywaar. As hulle in dic laerskool gehou word, sal hulle nooit daardie voorreg geniet nie.

\section{DIE TOELATINGSOUDERDOM.}

In Transvaal was dit die gebruik om leerlinge die eerste keer toe te laat in die halfjaar nadat hulle ses jaar oud geword het. Hulle was skoolpligtig sodra hulle sewe jaar oud geword het.

Die Nicol-kommissie (N.248) beveel aan „dat dit vir enige kind vrystaan on die skool binne te kom aan die begin van die eerste en derde kwartale as hy reeds ses jaar oud is of ses jaar sal word in die loop van dic kwartaal waarin hy toegelaat word" en verder „dat verpligte skoolbesoek in werking moet tree aan die begin van die halfjaar waarin hulle die ouderdom van sewe jaar bereik (N.247).

Die De Villiers-kommissie beveel aan dat alle vyfjarige kinders toegelaat word en dat "onderwys verpligtend moet wees tussen 6 en 16," d.w.s. vanaf die begin van die halfjaar wat onmiddellik op die sesde verjaarsdag volg (V.229).

By monde van die Transvaalse Onderwysersvereniging het die onderwysers sedert jare voorgestel dat leerlinge net een maal per jaar 
toegelaat word, en wel aan die begin van die jaar nadat hulle vyf-en-'n half jaar oud geword het. In groot skole waar die nuwelinge elke halfjaar 'n eie klas met 'n eie onderwyseres kon uitmaak, is die druk nooit gevoel nie, maar in die kleiner skole waar hulle by ' $n$ reeds swaar belaaide klas gevoeg moes word, kon die onderwyseres nie aan hulle of aan die vorige toelatings reg laat geskied nie.

Volgens die nuwe beleid kan leerlinge net een maal per jaar toegelaat word, en wel aan die begin van die jaar waarin hulle ses jaar oud word.

Oor die een toelating per jaar is die onderwysers verheug, maar die jeugdige ouderdom word deur baie afgekeur.

Terwyl die nuwe beleid dit as doel stel dat elke kind minstens twee of drie jaar in die middelbare skool moet deurbring om algemene onderwys te geniet en om beroepsvoorligting te ontvang en terwyl 'n kind die skool kan verlaat aan die einde van die jaar waarin hy sestien jaar oud word, volg dit noodwendig dat hy vroeër tot die laerskool toegelaat moet word.

Die Nicol-kommissie wou die leerling op dertienjarige leeftyd na die middelbare skool oorplaas. Maar as hy eers op sesjarige leeftyd toegelaat word, gee dit die laerskool onvoldoende tyd om hom vir die middelbare skool voor te berei. Die aanbeveling van die De Villiers-kommissie is derhalwe met enkele wysigings aanvaar.

In die praktyk beteken dit nou dat leerlinge op die ouderdom $13+$ na die middelbare skool oorgeplaas word, en dat hulle, wanneer hulle die skool op 16-jarige leeftyd verlaat, minstens beter toegerus sal wees om hulle by die lewe aan te pas.

\section{ALGEMENE OORSIG.}

Die kritiek dat die nuwe beleid oorhaastig ingevoer is terwyl dit die provinsie aan skoolruimte, onderwysers en ander fasiliteite ontbreek het, is nie ongegrond nie. Daarteenoor staan die oorweging dat as jy moet wag totdat die skoolgeboue, klaskamers, ameublement, skoolmateriaal en onderwysers alles gereed staan, jy nooit sover sal kom om 'n begin te maak nie. Een maal moet jy die stoute skoene aantrek en deurbyt. En as 'n saak eers staan, durf die belastingbetaler nie weier om die fasiliteite te verskaf nie.

Daar sal jarelank nog baie skaafplekke bestaan, en baie opofferings sal vereis word, maar in die breë gesien, kan die nuwe onderwysbeleid slegs tot voordeel van die kind strek, en dit is uiteindelik die vernaamste en enigste toets.

Op onderwysgebied het Suid-Afrika begin agter raak. En selfs na hierdie veranderings sal hy die agterstand nog nie inhaal nie. Solank die 
bevolking so wyd en yl versprei is, sal hy die agterstand ook nooit inhaal nie eenvoudig omdat hy dit nie kan bekostig nie. Die nuwe beleid sal darem daartoe bydra om die agterstand te verminder.

Die veranderings het nodig geword nie met die doel om in die mode te wees nie, nie om skole en leerplanne te organiseer soos hulle elders georganiseer is nie, maar om die onderwys by die eise van die ingewikkelde beskawing te laat aanpas. Vroeër kon 'n burger sonder standerd VI nog 'n eerbare bestaan voer, maar met die oog op die vinnige opkoms van die naturel moet hy minstens ' $n$ geskoolde arbeider wees as hy homself wil handhaaf. In ander lande verteenwoordig standerd VI nie meer 'n bepaalde hoeveelheid kennis nie, maar eerder 'n mate van liggaamlike, kulturele en maatskaplike ontwikkeling. Daar kan leerlinge op 'n sekere ouderdom as ambagsmanne opgelei word. Daardie ambagsmanne aanvaar geskoolde arbeid in Suid-Afrika. Is dit billik dat ons ons eie kinders daardie arbeid ontsê omdat hulle nie 'n bèpaalde kennispeil bereik het nie? Noodgedwonge moes ons ons onderwysstelsel hersien as ons ons eie kinders nie wou veronreg nie.

Ongelukkig moes die veranderings aangebring word sonder dat dit deur intensiewe navorsing in Suid-Afrika voorafgegaan is. Daar kan darem angevoer word dat dit deur minstens twee onderwyskommissies in een of ander vorm aanbeveel is. Navorsing sou die weg vergemaklik het, maar sou onwaarskynlik tot ander gevolgtrekkings gekom het. Van beplanning vooraf was daar byna nie sprake nie maar nogtans kan die doelstellings nie in twyfel getrek word nie.

\section{DIE TOEKOMS.}

Met hierdie veranderings is onderwyshervorming in Transvaal verreweg nog nie afgehandel nie. Baie vraagstukke wag nog op 'n oplossing. Net 'n paar daarvan word hier aangestip.

\section{(a) Eksamens.}

Byna alle eksamens is reeds afgeskaf, maar die belangrikste, die middelbare skooleindeksamen bly nog staan. Hierdie eksamen beïnvloed sonder twyfel ons onderwys aan die middelbare skool ten kwade. So spoedig moontlik moet dit deur iets doeltreffenders vervang word. Ook interne eksamens in die laerskool behoort nou afgeskaf te word.

Deur die ontwerping en toepassing van diagnostiese toetse op elke stadium van die onderwys en die aanwending van aanpassingsmetodes kan die onderwys baie doeltreffender gemaak word. Ons het nog veel te leer en veel te doen. 


\section{(b) Onderwyskoördinasie.}

Deur opvoedkundiges van naam word daar voortdurend op die nadele van die twee onderwysstelsels in Transvaal, die uniale en die provinsiale, gewys, maar die oplossing bly uitstaande. Die meeste denkers en skrywers beveel aan dat die staat hom vir alle onderwys in al die provinsies verantwoordelik moet stel. Ander denkers opper bedenkings teen ' $n$ uniale stelsel wat plaaslike inisiatief en ondernemingsgees kan smoor, en beveel aan dat elke provinsie alle onderwys binne sy grense, die universiteite uitgesonder, vir sy rekening moet neem en dit behoorlik moet koördineer. Daar bestaan reeds aanduidings dat die provinsiale owerhede van Transvaal in laasgenoemde rigting begin dink en werk.

Dis te hope dat ' $n$ oplossing spoedig gevind sal word.

\section{(c) Algemene Kulturele Onderwys.}

Sonder twyfel word hier te lande tot nadeel van die algemene kulturele vorming van ons jeug te vroeg gespesialiseer. Tereg het die De Villiers-kommissie aanbeveel dat elke leerling minstens drie jaar lank algemene onderwys aan 'n middelbare skool moet ontvang voordat hy toegelaat word om te gaan werk of hom in een of ander rigting toe te spits. Kennis sonder kultuur is mag sonder rigting.

Wat hierdie aangeleentheid betref, verdien die aanbevelings van die De Villiers-konmissie ernstige oorweging en daardwerklike optrede.

\section{(d) Landelike Onderwys.}

As gevolg van die sentralisasie van klein skooltjies is baie ligpunte in die platteland tot skade van die samelewing uitgedoof, en het gesinsontwrigting ingetree. Om gesinsontwrigting die hoof te bied, het baie gesinne hulle boerderye prysgegee en na die stede verhuis. Daardeur raak die platteland voortdurend meer ontvolk en verloor die land die kern van sy behoudende volkselement. Die plaasskooltjies het ook hulle beperkings gehad, maar hulle is verwyder en niks is in hulle plek gestel om die volk te dien nie. Dis 'n vraagstuk wat baie noukeurig ondersoek moet word.

\section{(e) Diverse.}

So bly daar nog baie onopgeloste vraagstukke soos die opleiding en voorsiening van onderwysers, skoolplase en sentrale skole skoolvoeding, naturelleonderwys, kleuteronderwys en volwasseneonderwys. 
Al hierdie vraagstukke moet planmatig bestudeer en aangepak word. Dit sal weliswaar geld kos, maar terwille van die toekoms mag ons op hierdie gebied nie suinig wees nie. Gelukkig beskik ons reeds oor wetenskaplik geskooldes .wat vir die nodige navorsingswerk behoorlik toegerus is. Al wat oorbly is om hulle kragte sonder verdere versuim aan te wend.

\section{P. J. VAN Z. HATTINGH.}

Johannesburg,

27 Februarie 1951. 